\title{
Dinamika dan Model Pengelolaan Populasi Ternak Kelinci Di Desa Karang Jaya Kabupaten Rejang Lebong
}

\author{
Dynamic and Management Models of Rabbit Population At Karang Jaya Distric \\ Rejang Lebong Region
}

Sutriyono

Jurusan Peternakan Fakultas Pertanian Universitas Bengkulu Jalan Raya Kandang Limun, Bengkulu. Telp. (0736) 2170 pst.219.

\begin{abstract}
The study was aimed to know dinamyc and management models of rabbit population at Rejang Lebong, the districts of Karang Jaya was chosen as sample and taken 30 farmers as responden. Data taken were by survey method and questioners. Analysis of data were calculated by descriptive statistic for birth rate, death rate, slaughter rate, and selling rate of rabbit per year or per month; and Powersim Constructor simulation program for management of population. Results showed that rabbit population increase was $62.2 \%$ per year or $5.18 \%$ per month, birth rate was $46.77 \%$ per month, death rate was $7.72 \%$ per month, slaughter rate was $6.57 \%$ per month, selling rate was 27.30 per month. Decreasing of death rate $50 \%$ with population level at 900 heads will increase the number of rabbit to selling $55 \%$ to $58 \%$ per month for time periode from 2010 to 2015.
\end{abstract}

Key words : Rabbit, population, dynamic, management model

\section{ABSTRAK}

Penelitian telah dilakukan dengan tujuan untuk mengevaluasi dinamika dan model pengelolaan populasi ternak kelinci di desa Karang Jaya Kecamatan Selupu Rejang Kabupaten Rejang Lebong Bengkulu, dari bulan Januari sampai Maret 2007. Sampel peternak kelinci diambil sebanyak 30 orang. Data yang dikumpulkan meliputi : jumlah ternak kelinci peliharaan, kelahiran, kematian, dijual, dipotong pada tahun 2006; dengan cara wawancara, pengisian daftar pertanyaan, dan pengamatan langsung di lapangan. Untuk mengetahui perkembangan populasi dan model pengelolaan populasi dilakukan simulasi dengan menggunakan program Powersim Constructor. Hasil penelitian menunjukkan bahwa laju kenaikkan populasi ternak kelinci adalah $62,2 \%$ per tahun atau 5,18 \% per bulan, dengan angka kelahiran 46,77\%; kematian : 7,72\%; dipotong 6,57 \%; dan dijual $27,30 \%$ per bulan. Dengan menurunkan angka kematian sebesar $50 \%$ dan populasi dipertahankan pada level 900 ekor akan meningkatkan jumlah ternak yang bisa dijual sebesar $55 \%$-58 \% per bulan untuk periode waktu 5 tahun dari 2010 sampai 2015.

Kata kunci : Kelinci, populasi, dinamika, model pengelolaan

\section{PENDAHULUAN}

Ternak kelinci merupakan komoditas penting bagi petani sayuran di Kabupaten Rejang Lebong. Kelinci mampu merubah sisa dan limbah sayuran untuk dirubah menjadi daging dan kotoran untuk pupuk sayuran, sehingga berperan penting dalam sistem ekonomi dan ekologi pertanian lahan kering. 
Peranan kelinci bagi peternak selain kedua hal tersebut adalah sebagai sumber protein bagi masyarakat pedesaan, sehingga dengan pemeliharaan kelinci yang mampu berkembang biak dengan cepat akan membantu dalam meningkatkan ketahanan pangan, khususnya dalam penyediaan sumber protein hewani bagi masyarakat.

$$
\text { Populasi merupakan suatu }
$$

kelompok individu dari spesies yang sama pada suatu tempat dan waktu (Setiadi dan Tjondronegoro, 1989), sehingga dengan bertambahnya waktu besarnya populasi akan berubah. Kelinci mempunyai kemampuan berkembang biak yang sangat cepat yaitu dalam setahun dapat beranak empat kali (Anonim, 2007), dengan jumlah anak dapat mencapai 6 -10 ekor per induk per kelahiran (Kartasubrata, 1994). Kematian ternak kelinci yang dibudidayakan masyarakat cukup tinggi yang dapat mencapai $15 \%$ $40 \%$ (Sarwono, 1991). Dua faktor tersebut sangat berpengaruh besar terhadap perkembangan populasi ternak kelinci, disamping faktor lain seperti : migrasi (imigrasi, emigrasi), pemotongan, dan awal pemeliharaan. Tingginya angka kelahiran dan tingginya angka kematian pada ternak kelinci menyebabkan populasi ternak kelinci sangat dinamis. Oleh karena itu pengelolaan terhadap ternak kelinci perlu dilakukan dalam upaya mempertahankan nilai ekonomis dan ekologis ternak kelinci sehingga dapat memberikan manfaat secara optimal bagi peternak kelinci. Mempertahankan angka kelahiran dan menekan angka kematian serta mempertahankan populasi sesuai dengan kemampuan peternak dan kepemilikan sumberdaya merupakan salah upaya untuk mengoptimalkan usaha ternak kelinci untuk memperoleh keuntungan yang optimal. Perlu dibuat suatu model pengelolaan populasi kelinci. Pada umumnya penyusunan model digunakan mode scenario dan dengan berbagai pilihan pengelolaan dapat dicoba. Meskipun hasilnya belum akurat tetapi dapat membantu dalam melakukan pengelolaan (Swartzman dan Kluzny, 1987).

Tujuan penelitian adalah mengkaji perkembangan populasi dan faktor-faktor yang mempengaruhi dinamika populasi ternak kelinci, estimasi populasi, dan model pengelolaan.

\section{MATERI DAN METODE}

Penelitian dilaksanakan dari bulan Januari sampai dengan bulan Maret 2007 di desa Karang Jaya Kecamatan Selupu Rejang Kabupaten Rejang Lebong. Sampel diambil sebanyak 30 orang peternak kelinci untuk mengkaji dinamika populasi. Data dikumpulkan melalui wawancara dengan peternak kelinci dan pengisian daftar pertnyaan. Data yang dikumpulkan meliputi data primer dan data sekunder. Data primer yang dukumpulkan adalah jumlah ternak kelinci peliharaan pada tahun 2006, yang kemudian dipisahkan menurut jenis kelamin, kelahiran, kematian, dipotong, dijual, dan pembelian dari luar desa. Kemudian dihitung bulanan dan tahunan untuk angka kelahiran (penentu laju kenaikkan populasi) dan angka kematian, angka pemotongan, dan angka penjualan (penentu laju penurunan populasi) dalam persen. Angka kelahiran, kematian, 
dipotong, dan dijual bulanan merupakan perbandingan antara jumlah ternak yang lahir dalam satu bulan dengan populasi pada awal bulan, kematian bulanan merupakan perbandingan antara ternak yang mati dengan populasi pada awal bulan, angka pemotongan bulanan merupakan perbandingan antara ternak yang dipotong dalam sebulan dengan populasi pada awal bulan, dan angka penjualan bulanan merupakan perbandingan antara ternak yang dijual dalam satu bulan dengan populasi awal bulan. Sedangkan angka tahunan merupakan rata-rata bulanan dikalikan dua belas. Data yang diperoleh ditabulasi kemudian dilakukan simulasi untuk mengetahui keadaan populasi kelinci pada berbagai waktu. Dibuat model diagram (Gambar 1) dan model matematis yang menghubungkan antar variabel Sedangkan data sekunder yang dikumpulkan antara lain adalah iklim, keadaan sosial ekonomi masyarakat peternak, dan manajemen pemeliharaan. Data yang diperoleh dari lapangan dan hasil simulasi ditabulasi dan dibahas secara deskriptif.

Sedangkan model matematis yang disusun dalam simulasi populasi kelinci adalah sebagai berikut :

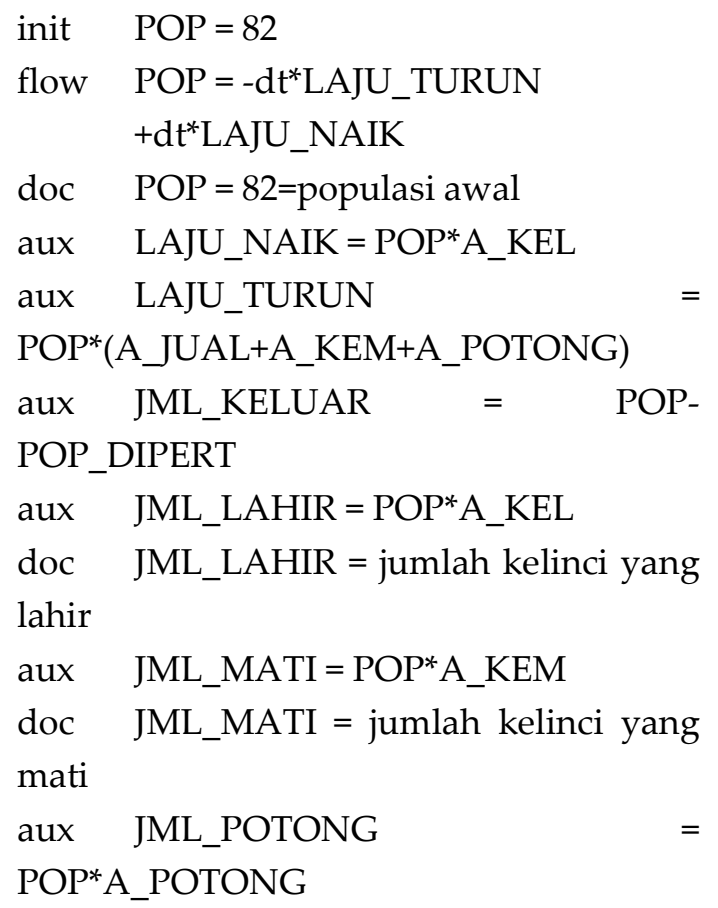

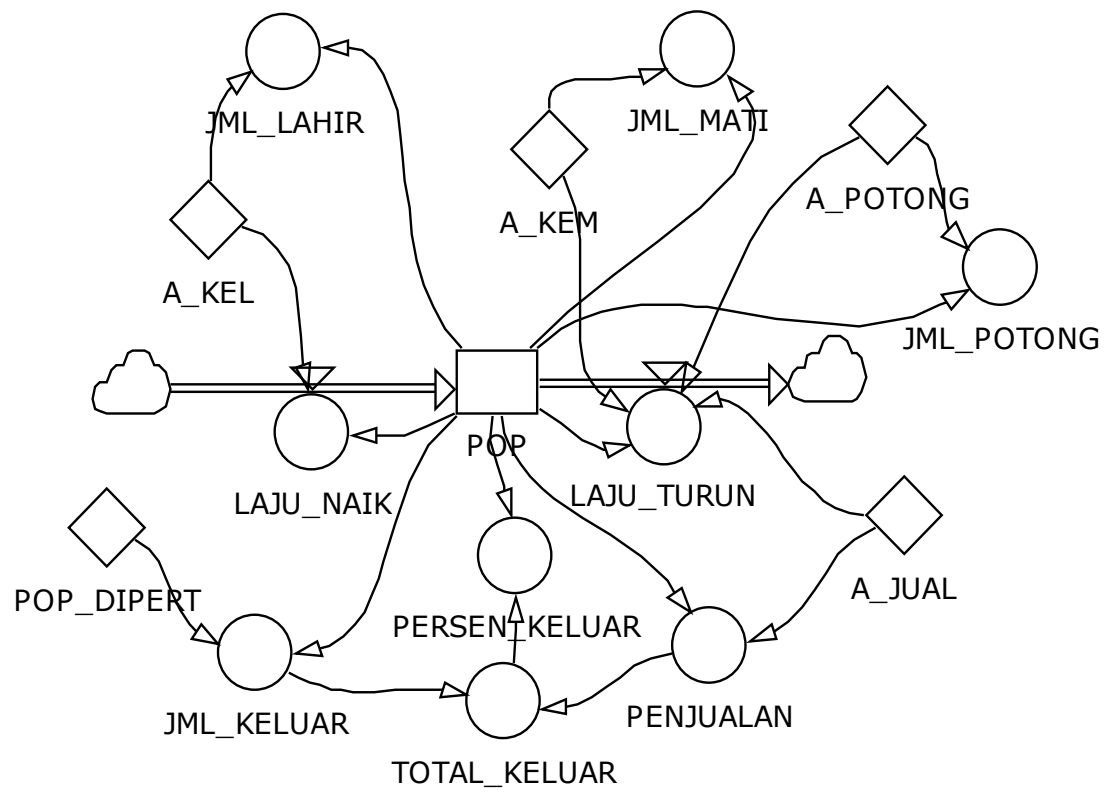

Gambar 1. Model diagram hubungan antar variabel yang berpengaruh terhadap dinamika populasi 
doc JML_POTONG $=$ jumlah kelinci dipotong

aux PENJUALAN $=$ POP ${ }^{*}$ A_JUAL

doc PENJUALAN = penjualan kelinci aux PERSEN_KELUAR = 100*TOTAL_KELUAR/POP aux TOTAL_KELUAR = JML_KELUAR+PENJUALAN doc TOTAL_KELUAR $=$ jumlah kelinci yang dikeluarkan dari populasinya

const A_JUAL $=327.5407468 / 100$

doc A_JUAL = Angka penjualan kelinci per tahun

const A_KEL $=561.2682319 / 100$

doc A_KEL $=$ Angka kelahiran kelinci per tahun

const A_KEM $=(92.58112649 / 100) / 2$

doc A_KEM = Angka kematian kelinci per tahun

const A_POTONG $=78.80964962 / 100$

doc A_POTONG = Angka pemotongan kelinci per tahun const POP_DIPERT $=1200$ ekor per tahun

doc POP_DIPERT = populasi

dipertahankan

\section{HASIL DAN PEMBAHASAN}

\section{Keadaan Umum Lokasi Penelitian}

Desa Karang Jaya termasuk dalam wilayah kecamatan Selupu Rejang Kabupaten Rejang Lebong, yang berjarak 3 kilometer dari ibukota kecamatan, 18 kilometer dari ibukota Kabupaten, dan 103 kilometer dari ibkota Propinsi. Batas wilayah sebelah utara adalah Taman Nasional Kerinci Seblat yang merupakan kawasan konservasi, sebelah timur berbatasan dengan desa Talang Lahat, sebelah selatan berbatasan dengan desa Mojorejo, dan sebelah barat berbatasan dengan desa Sumber Bening (Anonim, 2006). Luas lahan secara keseluruhan desa Karang Jaya adalah 650 ha dengan

Table 1. Perkembangan populasi kelinci di desa Karang Jaya kecamatan Selupu Rejang Kabupaten Rejang Lebong tahun 2006

\begin{tabular}{|c|c|c|c|c|c|c|c|c|c|c|c|c|c|c|c|}
\hline \multirow{2}{*}{ No } & \multirow{2}{*}{ Bulan } & \multirow{2}{*}{$\begin{array}{c}\text { Populasi } \\
\text { Awal Bulan }\end{array}$} & \multicolumn{2}{|c|}{ Kelahiran } & \multirow{2}{*}{$\begin{array}{l}\text { Total } \\
\text { lahir }\end{array}$} & \multicolumn{2}{|c|}{ Kematian } & \multirow{2}{*}{$\begin{array}{l}\text { Total } \\
\text { Mati }\end{array}$} & \multicolumn{2}{|c|}{ Dipotong } & \multirow{2}{*}{$\begin{array}{c}\text { Total } \\
\text { Dipotong }\end{array}$} & \multicolumn{2}{|c|}{ Dijual } & \multirow{2}{*}{$\begin{array}{c}\text { Total } \\
\text { Dijual }\end{array}$} & \multirow{2}{*}{$\begin{array}{r}\text { Populasi } \\
\text { akhir } \\
\text { bulan }\end{array}$} \\
\hline & & & Jantan & Betina & & Jantan & Betina & & Jantan & Betina & & Jantan & Betina & & \\
\hline \multirow[t]{2}{*}{1} & Januari & 82.00 & 31.00 & 42.00 & 73.00 & 5.00 & 7.00 & 12.00 & 6.00 & 0.00 & 6.00 & 13.00 & 12.00 & 25.00 & $112^{*}$ \\
\hline & & & 37.80 & 51.22 & 89.02 & 6.10 & 8.54 & 14.63 & 7.32 & 0.00 & 7.32 & 15.85 & 14.63 & 30.49 & ** \\
\hline \multirow[t]{2}{*}{2} & Pebruari & 112.00 & 25.00 & 35.00 & 60.00 & 3.00 & 5.00 & 8.00 & 4.00 & 5.00 & 9.00 & 20.00 & 13.00 & 33.00 & $122 *$ \\
\hline & & & 22.32 & 31.25 & 53.57 & 2.68 & 4.46 & 7.14 & 3.57 & 4.46 & 8.04 & 17.86 & 11.61 & 29.46 & ** \\
\hline \multirow[t]{2}{*}{3} & Maret & 122.00 & 20.00 & 2.00 & 22.00 & 6.00 & 3.00 & 9.00 & 3.00 & 5.00 & 8.00 & 16.00 & 12.00 & 28.00 & $99 *$ \\
\hline & & & 16.39 & 1.64 & 18.03 & 4.92 & 2.46 & 7.38 & 2.46 & 4.10 & 6.56 & 13.11 & 9.84 & 22.95 & ** \\
\hline \multirow[t]{2}{*}{4} & April & 99.00 & 19.00 & 28.00 & 47.00 & 7.00 & 5.00 & 12.00 & 6.00 & 3.00 & 9.00 & 18.00 & 15.00 & 33.00 & $92 *$ \\
\hline & & & 19.19 & 28.28 & 47.47 & 7.07 & 5.05 & 12.12 & 6.06 & 3.03 & 9.09 & 18.18 & 15.15 & 33.33 & ** \\
\hline \multirow[t]{2}{*}{5} & Mei & 92.00 & 30.00 & 20.00 & 50.00 & 5.00 & 4.00 & 9.00 & 8.00 & 2.00 & 10.00 & 17.00 & 20.00 & 37.00 & 86 * \\
\hline & & & 32.61 & 21.74 & 54.35 & 5.43 & 4.35 & 9.78 & 8.70 & 2.17 & 10.87 & 18.48 & 21.74 & 40.22 & ** \\
\hline \multirow[t]{2}{*}{6} & Juni & 86.00 & 28.00 & 33.00 & 61.00 & 9.00 & 2.00 & 11.00 & 6.00 & 0.00 & 6.00 & 8.00 & 11.00 & 19.00 & $111 *$ \\
\hline & & & 32.56 & 38.37 & 70.93 & 10.47 & 2.33 & 12.79 & 6.98 & 0.00 & 6.98 & 9.30 & 12.79 & 22.09 & ** \\
\hline \multirow[t]{2}{*}{7} & Juli & 111.00 & 21.00 & 39.00 & 60.00 & 0.00 & 4.00 & 4.00 & 3.00 & 0.00 & 3.00 & 15.00 & 26.00 & 41.00 & $123 *$ \\
\hline & & & 18.92 & 35.14 & 54.05 & 0.00 & 3.60 & 3.60 & 2.70 & 0.00 & 2.70 & 13.51 & 23.42 & 36.94 & $* *$ \\
\hline \multirow[t]{2}{*}{8} & Agustus & 123.00 & 36.00 & 18.00 & 54.00 & 5.00 & 3.00 & 8.00 & 4.00 & 4.00 & 8.00 & 17.00 & 12.00 & 29.00 & $132 *$ \\
\hline & & & 29.27 & 14.63 & 43.90 & 4.07 & 2.44 & 6.50 & 3.25 & 3.25 & 6.50 & 13.82 & 9.76 & 23.58 & ** \\
\hline \multirow[t]{2}{*}{9} & September & 132.00 & 20.00 & 27.00 & 47.00 & 0.00 & 4.00 & 4.00 & 3.00 & 6.00 & 9.00 & 15.00 & 13.00 & 28.00 & $138 *$ \\
\hline & & & 15.15 & 20.45 & 35.61 & 0.00 & 3.03 & 3.03 & 2.27 & 4.55 & 6.82 & 11.36 & 9.85 & 21.21 & ** \\
\hline \multirow[t]{2}{*}{10} & Oktober & 138.00 & 19.00 & 22.00 & 41.00 & 2.00 & 6.00 & 8.00 & 5.00 & 1.00 & 6.00 & 12.00 & 8.00 & 20.00 & 145 * \\
\hline & & & 13.77 & 15.94 & 29.71 & 1.45 & 4.35 & 5.80 & 3.62 & 0.72 & 4.35 & 8.70 & 5.80 & 14.49 & ** \\
\hline \multirow[t]{2}{*}{11} & November & 145.00 & 20.00 & 15.00 & 35.00 & 2.00 & 3.00 & 5.00 & 0.00 & 7.00 & 7.00 & 15.00 & 27.00 & 42.00 & $126^{*}$ \\
\hline & & & 13.79 & 10.34 & 24.14 & 1.38 & 2.07 & 3.45 & 0.00 & 4.83 & 4.83 & 10.34 & 18.62 & 28.97 & ** \\
\hline \multirow[t]{2}{*}{12} & Desember & 126.00 & 30.00 & 21.00 & 51.00 & 5.00 & 3.00 & 8.00 & 2.00 & 4.00 & 6.00 & 14.00 & 16.00 & 30.00 & 133 * \\
\hline & & & 23.81 & 16.67 & 40.48 & 3.97 & 2.38 & 6.35 & 1.59 & 3.17 & 4.76 & 11.11 & 12.70 & 23.81 & ** \\
\hline \multicolumn{3}{|c|}{ Jumlah (ekor) } & 299.00 & 302.00 & 601.00 & 49.00 & 49.00 & 98.00 & 50.00 & 37.00 & 87.00 & 180.00 & 185.00 & 365.00 & \\
\hline \multicolumn{3}{|c|}{ Rataan (ekor/bulan) } & 24.92 & 25.17 & 50.08 & 4.08 & 4.08 & 8.17 & 4.17 & 3.08 & 7.25 & 15.00 & 15.42 & 30.42 & \\
\hline Jum & ah (\%/tahun) & & 275.59 & 285.68 & 561.27 & 47.53 & 45.05 & 92.58 & 48.52 & 30.29 & 78.81 & 161.64 & 165.90 & 327.54 & \\
\hline Stan & dar Deviasi & & \pm 8.26 & \pm 13.66 & \pm 19.84 & \pm 3.10 & \pm 1.82 & \pm 3.84 & \pm 2.63 & \pm 1.89 & \pm 2.22 & \pm 3.47 & \pm 5.22 & \pm 7.30 & \\
\hline
\end{tabular}


ketinggian tempat 1102 meter di atas permukaan laut. Suhu udara berkisar antara $19,8^{\circ} \mathrm{C}$ sampai dengan $27,8^{\circ} \mathrm{C}$; kelembaban udara $70 \%$ sampai $90 \%$, dan curah hujan 15,1 milimeter per bulan dan rata-rata per tahun 2119 milimeter (Anonim, 2006). Lokasi tersebut cocok untuk budidaya ternak kelinci, yang mana ternak kelinci cocok dipelihara pada temperatus udara $15^{\circ} \mathrm{C}$ sampai dengan $20^{\circ} \mathrm{C}$, dengan kelembaban udara $60 \%$ sampai 90 \% (Sarwono, 2001).

\section{Keadaan Umum Responden}

Responden terpilih berpendidikan SD : 73,3\%, SLTP : 16,6 \%, dan sisanya adalah berpendidikan SLTA; dengan umur 25-53 tahun yang terdiri dari umur 25-35 tahun sebanyak 23,4\% dan 36-53 tahun $76,6 \%$. Pengalaman beternak kelinci berkisar antara 2 tahun sampai 10 tahun dengan perincian : 2-5 tahun sebanyak 66,6 \% dan 5 sampai 10 tahun sebanyak $33,4 \%$ (Anonim, 2006). Dengan tingkat pengalaman yang tinggi yang ditunjukkan oleh lamanya pemeliharaan akan mendukung perkembangan populasi. Mata pencaharian peternak kelinci mayoritas adalah petani sayuran sehingga sumber pakan ternak kelinci dapat berupa sisa dan limbah sayuran, khususnya pada saat panen. Disamping itu beberapa jenis hijauan yang ada di lahan sawah dapat digunakan sebagai sumber pakan kelinci, terutama pada saat tidak panen sayuran.

\section{Pemeliharaan Ternak Kelinci}

Ternak kelinci yang dipelihara adalah kelinci lokal dengan pemeliharaan dikandangkan. Kandang yang digunakan adalah kandang dengan sistem baterai sebanyak $80 \%$ peternak dan sistem koloni sebanyak $20 \%$ peternak. Sistem kandang baterai keselamatan ternak akan lebih terjamin, kematian anak dapat ditekan, perkelahian dan kanibalisme dapat dicegah, perkembangbiakan dapat diatur lebih mudah, kesempatan untuk mendapatkan ruangan dan pakan lebih terjamin. Pakan kelinci yang diberikan oleh peternak adalah wortel, kangkung, kubis, rumput lapang, daun ubi kayu, sawi, daun kacang panjang, dan daun ubi rambat. Sedangkan pakan penguat (konsentrat) tidak diberikan. Pakan diberikan pada pagi hari ( \pm jam 08.00 wib)

Tabel 2. Model Pengelolaan Dengan Tanpa Menurunkan Angka Kematian dan Populasi dipertahankan pada level 300 ekor

\begin{tabular}{cccccccccc}
\hline Tahun & $\begin{array}{c}\text { Jumlah } \\
\text { Lahir (ekor) }\end{array}$ & $\begin{array}{c}\text { Jumlah } \\
\text { mati (ekor) }\end{array}$ & $\begin{array}{c}\text { Jumlah } \\
\text { dipotong } \\
\text { (ekor) }\end{array}$ & $\begin{array}{c}\text { Jumlah } \\
\text { dijual } \\
\text { (ekor) }\end{array}$ & $\begin{array}{c}\text { populasi } \\
\text { (ekor) }\end{array}$ & $\begin{array}{c}\text { Populasi } \\
\text { dipertahankan } \\
\text { (ekor) }\end{array}$ & $\begin{array}{c}\text { Individu } \\
\text { dikeluarkan dari } \\
\text { populasi (ekor) }\end{array}$ & $\begin{array}{c}\text { Total keluar } \\
\text { dari populasi } \\
\text { (ekor) }\end{array}$ & $\begin{array}{c}\text { Individu } \\
\text { keluar dari } \\
\text { jumlah lahir } \\
(\%)\end{array}$ \\
\hline 2009 & 3,196 & 527 & 448 & 1,865 & 569 & 300 & 269 & 2,134 & 66.77 \\
2010 & 5,188 & 855 & 728 & 3,028 & 924 & 300 & 624 & 3,652 & 70.39 \\
2011 & 8,423 & 1,389 & 1,182 & 4,915 & 1500 & 300 & 1200 & 6,115 & 72.60 \\
2012 & 13,674 & 2,255 & 1,920 & 7,979 & 2,436 & 300 & 2136 & 10,115 & 73.97 \\
2013 & 22,198 & 3,661 & 3,116 & 12,954 & 3,955 & 300 & 3655 & 16,609 & 74.82 \\
2014 & 36,035 & 5,944 & 5,059 & 21,029 & 6,420 & 300 & 6120 & 27,149 & 75.34 \\
2015 & 58,499 & 9,649 & 8,214 & 34,138 & 10,422 & 300 & 10122 & 44,260 & 75.66 \\
\hline
\end{tabular}

Keterangan : data hasil simulasi 
dan sore hari ( \pm jam 16.00 wib). Keadaan tersebut berakibat pada rendahnya gizi bagi ternak kelinci, yang dapat berakibat pada rendahnya daya tahan kelinci terhadap serangan penyakit dan reproduksi. Kelinci membutuhkan konsentrat sebanyak $\pm 60 \%$ dan sisanya adalah hijauan (Sarwono, 2001). Kelinci merupakan jenis ternak pseudo-ruminan, yaitu herbivora yang tidak dapat mencerna pakan berserat secara baik dan fermentasi hanya terjadi pada caecum (bagian pertama usus besar) tetapi tidak mampu mencerna serat sebanyak ruminansia (Anonim, 2003 ). Berdasarkan pada uraian tersebut menunjukkan bahwa manajemen pemeliharaan, khususnya manajemen pemberian pakan belum menunjukkan standar manajemen pemeliharaan yang baik.

\section{Perkembangan Populasi Kelinci}

Populasi mempunyai karakteristik yang selalu berubah-ubah (dinamis) sejalan dengan waktu. Faktor-faktor yang menyebabkan terjadinya dinamika populasi adalah kelahiran, kematian, imigrasi dan emigrasi (Tarumingkeng, 1994). Untuk populasi ternak kelinci perubahan populasi disebabkan oleh adanya kelahiran, kematian, dipotong, dijual keluar daerah (emigrasi), hilang, dan dibeli dari luar daerah (imigrasi). Kondisi perkembangan populasi kelinci di desa Karang Jaya tertera pada Tabel 1. Pada Tabel tersebut ditunjukkan bahwa pada awal tahun 2006 total populasi kelinci di desa Karang Jaya adalah 82 ekor. Dalam kurun waktu satu tahun populasi berubah menjadi 133 ekor atau naik 62,195 $\%$ per tahun atau 5,18 \% per bulan, dengan tingkat kematian kelinci rata-rata per bulan adalah : 7,72 \%; dipotong 6,57 \%; dan dijual 27,30\%. Sedangkan tingkat kelahiran adalah $732,93 \%$ per tahun atau $61,077 \%$ per bulan dari populsi awal. Jika dibandingkan antara variabel penentu laju naik (kelahiran) dengan penentu laju turun (kematian, dipotong, dijual) maka nilai nilai variabel penentu laju naik masih lebih tinggi. Namun demikian kenaikkan populasi masih sangat rendah jika dilihat secara keseluruhan dari awal tahun sampai akhir tahun. Rendahnya angka pertambahan tersebut antara lain disebabkan oleh rendahnya angka kelahiran yang besarnya adalah 601 ekor selama setahun. Jika ditinjau dari sisi

Tabel 3. Model Pengelolaan Dengan Tanpa Menurunkan Angka Kematian dan Populasi dipertahankan pada level 900 ekor

\begin{tabular}{cccccccccc}
\hline Tahun & $\begin{array}{c}\text { Jumlah } \\
\text { Lahir(ekor) }\end{array}$ & $\begin{array}{c}\text { Jumlah } \\
\text { mati (ekor) }\end{array}$ & $\begin{array}{c}\text { Jumlah } \\
\text { dipotong } \\
\text { (ekor) }\end{array}$ & $\begin{array}{c}\text { Jumlah } \\
\text { dijual } \\
\text { (ekor) }\end{array}$ & $\begin{array}{c}\text { populasi } \\
\text { (ekor) }\end{array}$ & $\begin{array}{c}\text { Populasi } \\
\text { dipertahankan } \\
\text { (ekor) }\end{array}$ & $\begin{array}{c}\text { Individu } \\
\text { dikeluarkan dari } \\
\text { populasi (ekor) }\end{array}$ & $\begin{array}{c}\text { Total keluar } \\
\text { dari populasi } \\
\text { (ekor) }\end{array}$ & $\begin{array}{c}\text { Individu } \\
\text { keluar dari } \\
\text { jumlah lahir } \\
(\%)\end{array}$ \\
\hline 2009 & 3196 & 527 & 448 & 1865 & 569 & 900 & -331 & 1,534 & 48.00 \\
2010 & 5188 & 855 & 728 & 3028 & 924 & 900 & 24 & 3,052 & 58.83 \\
2011 & 8423 & 1389 & 1182 & 4915 & 1500 & 900 & 600 & 5,515 & 65.48 \\
2012 & 13674 & 2255 & 1920 & 7979 & 2436 & 900 & 1536 & 9,515 & 69.58 \\
2013 & 22198 & 3661 & 3116 & 12954 & 3955 & 900 & 3055 & 16,009 & 72.12 \\
2014 & 36035 & 5944 & 5059 & 21029 & 6420 & 900 & 5520 & 26,549 & 73.68 \\
2015 & 58499 & 9649 & 8214 & 34138 & 10422 & 900 & 9522 & 43,660 & 74.63 \\
\hline Ketarangan : data hasil simulasi & & & & & & & & &
\end{tabular}


frekuensi melahirkan dan jumlah anak per kelahiran, seekor induk kelinci memiliki kemampuan reproduksi yang tinggi yaitu mampu beranak 4 kali per tahun dengan lama bunting berkisar antara 28-31 hari dan jumlah anak 6-10 ekor per kelahiran (Subroto, 2001), dengan jumlah kelahiran sebanyak 50 ekor per tahun (Anonima, 2003). Dengan populasi awal tahun 82 ekor dan pada akhir tahun 133 ekor maka dapat dikategorikan perkembangan populasinya adalah lambat. Faktor penyebab rendahnya pertumbuhan populasi adalah kelahiran yang rendah, tingginya angka kematian, pemotongan, dan penjualan ternak kelinci. Pertumbuhan populasi dapat ditingkatkan dengan melakukan pengelolaan populasi melalui modifikasi variabel penentu laju naik dan laju turun. Upaya yang dapat dilakukan antara lain adalah dengan menurunkan angka kematian dan mempertahankan popolasi pada tingkat yang seimbang dengan ketersediaan sumberdaya yang dimiliki petani.

\section{Model Pengelolaan Populasi}

Dalam membuat model digunakan beberapa asumsi-asumsi, yaitu : tidak ada perubahan secara mendadak yang mengganggu kestabilan populasi seperti perubahan lingkungan yang ekstrim yang dapat mengganggu fisiologi hewan dan ketersediaan pakan, wabah penyakit yang mematikan, serta keadaan ekonomi peternak. Dua variabel penentu pertumbuhan populasi yang dimanipulasi adalah menurunkan angka kematian. Tingkat kematian pada ternak kelinci terjadi antara lain adalah keadaan kandang yang tidak memenuhi syarat. Sukri (2004) melaporkan bahwa kematian kelinci dikarenakan dimakan hewan buas, terjepit kandang, dan lepas dari kandang dan ditemukan sudah dalam keadaan mati. Dijelaskan juga bahwa kematian pada ternak terjadi pada masa umur muda (anak). Poole (1974) mengemukakan bahwa kepadatan populasi akan mempengaruhi pertumbuhan populsi itu sendiri. Kepadatan kandang yang tinggi akan menyebabkan terjadinya kompetisi dalam mendapatkan pakan dan ruangan. Dalam kelompok ternak, khususnya dalam kandang akan terbentuk kondisi sosial yang mantap sehingga akan ada ternak dominan dan sub ordinat. Ternak yang tidak dominan akan mendapatkan kesempatan yang kurang baik, dalam mendapatkan pakan, ruangan, dan

Tabel 4. Model Pengelolaan Dengan Menurunkan Angka Kematian 50 \% dan Populasi dipertahankan pada level 300 ekor

\begin{tabular}{cccccccccc}
\hline Tahun & $\begin{array}{c}\text { Jumlah } \\
\text { Lahir (ekor) }\end{array}$ & $\begin{array}{c}\text { Jumlah } \\
\text { mati (ekor) }\end{array}$ & $\begin{array}{c}\text { Jumlah } \\
\text { dipotong } \\
\text { (ekor) }\end{array}$ & $\begin{array}{c}\text { Jumlah } \\
\text { dijual } \\
\text { (ekor) }\end{array}$ & $\begin{array}{c}\text { populasi } \\
\text { (ekor) }\end{array}$ & $\begin{array}{c}\text { Populasi } \\
\text { dipertahankan } \\
\text { (ekor) }\end{array}$ & $\begin{array}{c}\text { Individu } \\
\text { dikeluarkan dari } \\
\text { populasi (ekor) }\end{array}$ & $\begin{array}{c}\text { Total keluar } \\
\text { dari populasi } \\
\text { (ekor) }\end{array}$ & $\begin{array}{c}\text { Individu } \\
\text { keluar dari } \\
\text { jumlah lahir } \\
(\%)\end{array}$ \\
\hline 2009 & 8719 & 719 & 1224 & 5088 & 1553 & 300 & 1253 & 6341 & 72.73 \\
2010 & 18190 & 1500 & 2554 & 10615 & 3240 & 300 & 2940 & 13555 & 74.52 \\
2011 & 37949 & 3129 & 5328 & 22146 & 6761 & 300 & 6461 & 28607 & 75.38 \\
2012 & 79173 & 6529 & 11117 & 46203 & 14106 & 300 & 13806 & 60009 & 75.79 \\
2013 & 165178 & 13623 & 23193 & 96393 & 29429 & 300 & 29129 & 125522 & 75.99 \\
2014 & 344606 & 28421 & 48387 & 201103 & 61397 & 300 & 61097 & 262200 & 76.09 \\
2015 & 718944 & 59294 & 100949 & 419556 & 128092 & 300 & 127792 & 547348 & 76.13 \\
\hline Keterangan : data hasil simulasi & & & & & & &
\end{tabular}


Tabel 5. Model Pengelolaan Dengan Menurunkan Angka Kematian 50\% dan Populasi dipertahankan pada level 900 ekor

\begin{tabular}{cccccccccc}
\hline Tahun & $\begin{array}{c}\text { Jumlah } \\
\text { Lahir(ekor) }\end{array}$ & $\begin{array}{c}\text { Jumlah } \\
\text { mati (ekor) }\end{array}$ & $\begin{array}{c}\text { Jumlah } \\
\text { dipotong } \\
\text { (ekor) }\end{array}$ & $\begin{array}{c}\text { Jumlah } \\
\text { dijual } \\
\text { (ekor) }\end{array}$ & $\begin{array}{c}\text { populasi } \\
\text { (ekor) }\end{array}$ & $\begin{array}{c}\text { Populasi } \\
\text { dipertahankan } \\
\text { (ekor) }\end{array}$ & $\begin{array}{c}\text { Individu } \\
\text { dikeluarkan dari } \\
\text { populasi (ekor) }\end{array}$ & $\begin{array}{c}\text { Total keluar } \\
\text { dari populasi } \\
\text { (ekor) }\end{array}$ & $\begin{array}{c}\text { Individu } \\
\text { keluar dari } \\
\text { jumlahlahir } \\
(\%)\end{array}$ \\
\hline 2009 & 8719 & 719 & 1224 & 5088 & 1553 & 900 & 653 & 5741 & 65.84 \\
2010 & 18190 & 1500 & 2554 & 10615 & 3240 & 900 & 2340 & 12955 & 71.22 \\
2011 & 37949 & 3129 & 5328 & 22146 & 6761 & 900 & 5861 & 28007 & 73.80 \\
2012 & 79173 & 6529 & 11117 & 46203 & 14106 & 900 & 13206 & 59409 & 75.04 \\
2013 & 165178 & 13623 & 23193 & 96393 & 29429 & 900 & 28529 & 124922 & 75.63 \\
2014 & 344606 & 28421 & 48387 & 201103 & 61397 & 900 & 60497 & 261600 & 75.91 \\
2015 & 718944 & 59294 & 100949 & 419556 & 128092 & 900 & 127192 & 546748 & 76.05 \\
\hline
\end{tabular}

Keterangan : data hasil simulasi

kesempatan untuk pemeliharaan anak. Hal tersebut dapat menyebabkan terjadinya kematian yang tinggi (Tomaszweska, dkk. 1991). Oleh sebab itu untuk menekan angka kematian dapat dilakukan dengan memperbaiki manajemen pemeliharaan, khususnya perbaikan kandang dan perbaikan mutu pakan. Dengan jumlah pakan yang cukup dari segi kualitas dan kuantitas maka ternak kelinci tidak akan berusaha keluar kandang untuk mencari makan. Pengelolaan populasi dengan menekan angka kematian akan menghasilkan pertumbuhan populasi yang tinggi, yang pada suatu saat akan terjadi peledakan populasi yang melebihi daya dukung sumberdaya yang dimiliki oleh petani. Pembatasan terhadap populasi perlu dilakukan melalui pengeluaran individu ternak kelinci dengan cara dijual atau dipotong sehingga terjadi keseimbangan antara populasi dan sumberdaya yang dimiliki oleh peternak kelinci.

Dalam pengelolaan populasi kelinci ada beberapa skenario yang dibuat melalui manipulasi variabel yang menentukan perkembangan populasi. Pada penelitian ini hanya dua variabel yang dikelola yaitu kematian dan penjualan ternak kelinci. Skenario 1 : angka kematian tidak diturunkan dan populasinya dipertahankan pada tingkat 300 ekor per tahun, skenario 2 : angka kematian tidak diturunkan dan populasinya dipertahankan pada tingkat 900 ekor per tahun, Skenario 3: menurunkan angka kematian $50 \%$ dengan populasi dipertahankan 300 ekor per tahun, skenario 4 : menurunkan angka kematian $50 \%$ dengan populasi dipertahankan 900 ekor per tahun.

Hasil simulasi menunjukkan bahwa dengan menurunkan angka kematian sebesar $50 \%$ dan populasi dipertahankan pada level 300 ekor per tahun maka kelinci yang dapat dijual pada tahun 2015 adalah 547,348 ekor (Tabel 4), dan jika angka populasi yang sipertahankan 900 ekor per tahun maka pada tahun 2015 kelinci yang siap untuk dijual diperkirakan dapat mencapai 
546,748 ekor (Tabel 5). Jika dibandingkan dengan tanpa menurunkan angka kematian maka nilai tersebut lebih tinggi. Pada Tabel 2 ditunjukkan bahwa dengan tidak menurunkan angka kematian maka jumlah ternak kelinci yang dapat dijual pada tahun 2015 adalah 44,260 ekor pada populasi yang dipertahankan 300 ekor, sedangkan pada tingkat populasi yang dipertahankan 900 ekor maka jumlah kelinci yang dapat dijual adalah 43,660 ekor (Tabel 3). Dengan menurunkan angka kematian sebesar $50 \%$ diperkirakan akan terjadi kenaikkan angka penjualan sebesar $55 \%$ per bulan untuk kurun waktu 5 tahun dari tahun 2010 sampai tahun 2015 dengan populasi yang dipertahankan 300 ekor. Sedangkan jika populasi dipertahankan 900 ekor maka terjadi angka kenaikkan penjualan sebesar $58 \%$ per bulan.

\section{SIMPULAN}

Dinamika populasi ternak kelinci ditentukan oleh beberapa faktor yaitu adanya kelahiran (variabel penentu laju naik), kematian, dipotong, dan dijual (variabel penentu laju turun. Besarnya nilai variabel adalah sebagai berikut : kelahiran $=561,27 \%$ per tahun atau 46,77 per bulan; kematian $=92,58 \%$ per tahun atau $7,72 \%$ per bulan; dipotong $=78,81 \%$ per tahun atau 6,57 per bulan; 327,54\% per tahun atau $27,30 \%$ per bulan dari populasi awal.

Pengelolaan populasi melalui penurunan angka kematian dan pembatasan populasi akan meningkatkan jumlah ternak yang dapat dijual. Dengan menekan angka kematian sampai $50 \%$ dan level populasi dipertahankan 900 ekor maka dapat diestimasikan jumlah ternak kelinci yang dapat dijual meningkat sebesar $55 \%$ sampai $58 \%$ per bulan untuk selama periode waktu 5 tahun (2010-2015) dari pada tanpa menurunkan angka kematian populasi. .

\section{DAFTAR PUSTAKA}

Anonim, 2003a . Peternakan Kelinci.httb://Warintek progresio.or.id. 13 Mei 2003.

Anonim, 2003 ${ }^{\text {b }}$ Rabbit Rearing. http://www.doa.sarawak.gov.my/r abbit.html.cached. 16 Juni 2003.

Anonim, 2006. Data Dasar Profil Desa/Kelurahan Karang Jaya Kecamtan Selupu. Rejang Kabupaten Rejang Lebong. Bengkulu.

Anonim, 2007. Budidaya Ternak Kelinci. http://www.Ristek.go.id.html. Diakses 07 Juni 2007.

Poole, R.W. 1974. An Introduction to Quantitative Ecology. McGrawHill Book Company. New York.

Sarwono, B. 2001. Kelinci Potong dan Hias. Agro Media Pustaka. Jakarta.

Setiadi, D. dan P.D. Tjondronegoro, 1989. Dasar-dasar Ekologi. Departemen Pendidikan dan Kebudayaan. Direktorat Jenderal Pendidikan Tinggi-PAU Hayati Institut Pertanian Bogor.

Subroto, S. 2001. Beternak Kelinci. Aneka Ilmu. Semarang.

Sukri, 2004. Hubungan manajemen pemberian pakan terhadap perkembangan populasi kelinci lokal di desa Mojorejo kecamatan 
Sindang Kelingi kabupaten Rejang Lebong. Jurusan Peternakan Fakultas Pertanian UNIB. Bengkulu. (Skripsi)

Swartzman, G.L. dan S.P. Kluzny. 1987. Ecological Simulation Primer. MACMILLAN Publisher Company. New York.

Tarumingkeng, R.C. 1994. Dinamika Populasi. Kajian Ekologi Kuantitatif. Pustaka Sinar Harapan dan Universitas Kristen Krida Wacana. Jakarta.

Tomaszweska, M.W. dan I.K. Sutama, I.G. Putu, dan T.D. Chaniago. 1991. Reproduksi, Tingkah Laku, dan Produksi Ternak di Indonesia. Gramedia Pustaka Utama. Jakarta. 